\title{
Economia Solidária: uma experiência intercultural
}

\section{Solidarity economy: an intercultural experience}

\author{
Dinora Tereza-Zuchetti* \\ Eliana Perez-Gonçalves de Moura* \\ Magali Mendes-de Menezes**
}

\begin{abstract}
This paper discuss the possible approximations among the sympathetic economy \& the intercultural studies. Picking demonstrate how the sympathetic economy-more than only one alternative viable the capitalism - can be a effective tool to social transformation, presents the social and economic scene from the politicals \& economic practices of the sympathetic economy, into the Brazilian ambit. Propose a critical \& contexting reflection about its potentialities from this approximation, highlighting the properties \& convergences among sympathetic economy \& from the intercultural studies field.
\end{abstract}

Keywords: sympathetic economy, intercultural studies, Brazilian scene.

\begin{abstract}
Resumo
Este ensaio discute as possíveis aproximações entre a economia solidária e os estudos interculturais. Buscando demonstrar como a economia solidária -mais do que uma alternativa viável ao capitalismo- pode constituir-se numa ferramenta efetiva de transformação social, apresenta o panorama socioeconômico decorrente das práticas políticas e econômicas da economia solidária, no âmbito brasileiro. Propóe uma reflexão crítica e contextualizada acerca das potencialidades desta aproximação, realçando as características e convergências entre economia solidária e o campo dos estudos interculturais.
\end{abstract}

Palavras-chave: economia solidária, estudos interculturais, cenário brasileiro.

*Universidade Feevale, Brasil. Correo-e: dinora@feevale.br; elianapgm@feevale.br.

** Associaçáo Sul Americana de Filosofia e Teologia Interculturais (ASAFTI), Brasil. Correo-e: magalim@feevale.br. 


\section{Introdução}

As experiências no campo da economia solidária no Brasil resultam de um longo e perseverante processo de luta dos/as trabalhadores/as contra as desigualdades provocadas pelo capitalismo. Tais experiências vêm conquistando um lugar de destaque no processo de desenvolvimento sócioeconômico, político e cultural brasileiro, bem como têm ampliado os espaços de debates a nível nacional, produzindo outras formas de organização social expressas, por exemplo, no Fórum Brasileiro de Economia Solidária ${ }^{1}$ e, mais recentemente, na $1^{\text {a }}$ Conferência Nacional de Economia Solidária. $^{2}$

Demonstrando grande vitalidade, a expansão dessas experiências consagra a economia solidária como um modelo efetivo de geração de trabalho e renda, baseadas no associativismo solidário. ${ }^{3}$ Nesse sentido, existe hoje, no Brasil, um considerável acúmulo teórico voltado às questôes técnicas de viabilidade econômica, desenvolvimento de tecnologias para o aperfeiçoamento de produtos e/ou serviços, redes de comercialização, linhas de financiamento e formação/capacitaçáo para a gestão dos empreendimentos, entre outros.

Além disso, destacam-se importantes avanços com relação ao desenvolvimento de tecnologias de incubação e assessoramento técnico fornecidos por diversas entidades apoiadoras -basicamente, universidades e

\footnotetext{
${ }^{1}$ Criado em 2001 para articular e mediar a participação nacional e das redes internacionais da economia solidária no I FSM, o Grupo de Trabalho Brasileiro de Es (GTBrasileiro) constituiu-se por organizaçóes e redes de uma diversidade de práticas e segmentos da economia popular solidária: campo, cidade, práticas diminutas, práticas complexas, igreja, bases populares, bases sindicais, universidades, movimentos sociais populares, práticas governamentais, práticas de apoio ao crédito, práticas de redes de informação, vínculos às bases nacionais, vínculos às redes internacionais. As 12 entidades e redes nacionais de fomento que em momentos e níveis diferentes participaram do gtbrasileiro são: Rede Brasileira de Socioeconomia Solidária (RBSES); Instituto Políticas Alternativos para o Cone Sul (PACS); Federação de Órgãos para a Assistência Social e Educacional (FASE); Associação Nacional dos Trabalhadores de Empresas em Auto-Gestão (ANTEAG); Instituto Brasileiro de Análises Sócio-Econômicas (IBASE); Cáritas Brasileira; Movimento dos Trabalhadores Sem Terra (MST/Concrab); Rede Universitária de Incubadoras Tecnológicas de Cooperativas Populares (ITCP); Agência de Desenvolvimento Solidário (ADS/CUT); Unitrabalho; Rede Brasileira de Gestores de Políticas Públicas da Economia Solidária; Associação Brasileira de Instituições de Micro-Crédito (Abicred), http:// www.fbes.org.br, 25-vII-2008.

${ }^{2}$ Realizada em Brasília, no mês de junho 2006, a I Conferência Nacional de Economia Solidária, visou afirmar a Economia Solidária como estratégia e política de desenvolvimento; debater e propor princípios e diretrizes para a Política Nacional de Economia Solidária; avaliar a situação e o potencial da Economia Solidária no país, tanto do ponto de vista de sua organização social quanto das políticas públicas desenvolvidas; e, propor estratégias e prioridades para as políticas e programas de fortalecimento da Economia Solidária, http://www.mte.gov.br/ecosolidaria/conf_default.asp, 25-VII-2008.

${ }^{3}$ No âmbito deste texto, usaremos indistintamente as expressôes empreendimentos, grupo e/ou cooperativas solidárias para nos referirmos às experiências que são orientadas por princípios solidários, fundados numa perspectiva de articulação da autogestão e da solidariedade, da viabilidade econômica, da preservação ambiental, da cidadania ativa e das potencialidades éticas em favor da vida.
} 
ONG- aos grupos em formação ou em fase de consolidação. No presente artigo, buscamos refletir sobre esta mobilização social percebendo-a como um espaço significativo de produção e troca de saberes, permeados pela experiência intercultural.

\section{O surgimento da economia solidária no Brasil}

O novo ciclo de acumulação flexível do capitalismo afetou o mundo inteiro e, especialmente, no Brasil, causou modificaçóes importantes na estrutura social, na distribuição da renda e no trabalho assalariado, gerando crescentes níveis de pobreza. Nas últimas décadas, milhóes de trabalhadores/as foram excluídos dos seus empregos e empurrados/as ao trabalho precário, sem garantias de direitos, aumentando o distanciamento entre ricos e pobres, e provocando um acentuado crescimento da desigualdade social, manifestada pela degradação de bens coletivos, tais como: educação, saúde, habitação, previdência social, etc. ${ }^{4}$

Neste contexto, as circunstâncias de vida e as condiçóes de crescente miserabilidade da maioria da populaçáo têm provocado o surgimento de experiências de trabalho coletivo que, absorvendo o grande contingente de excluídos, convoca as pessoas a serem partícipes da construção de uma caminhada, onde a participaçáo, a autonomia e uma sensibilidade solidária permitem novas formas de (com)vivência.

As primeiras experiências de empreendimentos solidários no Brasil começaram a ganhar mais visibilidade na década 1980 e se tornaram comuns a partir da metade da década de 1990. Elas são resultantes de vários movimentos sociais que se mobilizaram diante da crise de desemprego que assolou o país a partir de 1981 e agravou-se no início dos anos 90, com a abertura de mercado brasileiro para os produtos importados. Segundo Singer (2000), as primeiras experiências resultaram do apoio de sindicatos a alguns grupos de operários que assumiram o controle administrativo da massa falida de empresas, visando manter seus postos de trabalho; os quais formaram, mais tarde, a Associaçáo Nacional de Trabalhadores de Empresas Autogestionárias e de Participação Acionária (ANTEAG).

Todavia, a consolidação dessas experiências associativas no Brasil, também contou com o apoio fundamental do Movimento dos Trabalhadores Rurais Sem Terra (MST), na medida em que este adotou a organização de diferentes tipos de cooperativas, como estratégia para garantir a viabilida-

\footnotetext{
${ }^{4}$ Segundo dados da CEPAl os $5 \%$ mais ricos na América Latina abarcam $50 \%$ da renda, enquanto os $30 \%$ mais pobres detêm apenas $7.5 \%$. Essa grande concentraçáo de renda é a principal responsável pela violência crescente que afeta a sobrevivência dos seres humanos, http://www.cepal.org/ brasil.
} 
de econômica das áreas assentadas. Também foram fundamentais as experiências e reflexóes advindas das Comunidades Eclesiais de Base, motivadas no Brasil pelo debate em torno da Teologia da Libertação, na busca de alternativas à sobrevivência que fossem capazes de traduzir, de alguma forma, esta experiência mística que emergia da solidariedade entre as pessoas. Singer (2000) cita também as experiências das Incubadoras Tecnológicas de Cooperativas Populares (ITCP), que funcionam ligadas a universidades, como fortalecedoras do cooperativismo solidário no Brasil, visando organizar grupos de trabalhadores em torno de cooperativas de trabalho ou de produção dando apoio administrativo e jurídico.

\subsection{O modelo teórico da economia solidária brasileira}

A economia solidária tem se disseminado cada vez mais no Brasil, como uma possibilidade de sobrevivência das camadas da população excluídas do mercado de trabalho formal. Manifesta-se sob diferentes formas organizativas (comunitárias, associativas, familiares, cooperativadas, etc.), construídas sobre princípios gerais que se fundamentam na prática da autogestão, caracterizada por tomadas de decisão mais democráticas, relaçôes sociais de cooperação entre pessoas e grupos e pela horizontalidade nas relaçóes sociais em geral.

Paul Singer, um dos principais expoentes que trabalha com esta temática, no Brasil, define a economia solidária como:

...um modo de produção que se constitui ao lado do modo de produção capitalista, da pequena produção de mercadorias, da produção estatal, da produção privada sem fins de lucro. [...] Todos esses modos de produção compóem a formaçáo social capitalista que só é capitalista porque o capitalismo é o maior modo de produçáo e molda a superestrutura legal e institucional à sua lógica (2002a: 22).

Segundo sua concepção, "a economia solidária deverá aproveitar-se do desenvolvimento das forças produtivas; relacionar-se com o mercado capitalista, não privilegiar, nem buscar o isolamento; não prescindir inteiramente do Estado, mas deve buscar a sua autonomia e ter como base a história do movimento anticapitalista” (p. 23).

Além de Paul Singer, inúmeros outros pesquisadores ${ }^{5}$ brasileiros têmse dedicado à esta temática, concebendo a economia solidária enquanto uma forma viável de superação da ordem capitalista. Entretanto, não há unanimidade entre eles em relação a diversos pontos. Por exemplo, no

\footnotetext{
${ }^{5}$ Dentre tantos, destacam-se: Marcelo Lopes de Souza; Enrique Leff; Luís Razeto; Luís Ignácio Gaiger; Armando Lisboa e Euclides Mance.
} 
que tange às origens da economia solidária, Paul Singer (2002a) situa-a nos utópicos (há cerca de 200 anos), enquanto que há aqueles que afirmam (Razeto, 1999) que sempre houve na história da humanidade alguma forma de expressão econômica que pode ser entendida como solidária.

Retomando a discussão entre os pesquisadores brasileiros, com relação ao desenvolvimento das forças produtivas, percebemos também divergências que de alguma forma enriquecem o debate. Para Singer (2002a), necessariamente, a economia solidária deverá incorporar as forças produtivas desenvolvidas no modo de produção capitalista. Para Mance (2000), ela deverá, sim, estar inserida no desenvolvimento produtivo atual, mas poderá criar a sua própria tecnologia e atuar em forma de redes próprias e, segundo Lisboa (2001), ela deverá desenvolver-se a partir de uma dinâmica local a fim de criar uma sociedade mais justa.

Quanto à sua ligação com o modo de produção capitalista, para Singer (2002b), ela não deverá atuar isoladamente, mas vinculada à sociedade do capital. Para Razeto (1999), a racionalidade da solidariedade poderá ser adotada por toda a sociedade, desde empresas até o Estado. Para Lisboa (2001), ela estará atuando em um mercado controlado pela sociedade; e para Gaiger (2001), assim como Singer (2002b), ela não estará desatrelada do capitalismo, mas atuará sob a forma da solidariedade.

No que se refere a sua dinâmica, para Singer (2000), esta advém da autogestão; para Mance (2000), advém do consumo solidário; sendo que para Gaiger (2000) e Razeto (1999) sua dinâmica advém de uma racionalidade solidária ou de uma racionalidade empreendedora.

Por fim, quanto ao seu vínculo com o Estado, Singer (2003) entende que a economia solidária deverá manter uma certa autonomia em relação ao Estado, embora ele seja necessário para uma distribuição equânime dos resultados do processo produtivo. E, para Razeto (1999), se o Estado adotar a racionalidade solidária, suas políticas serão mais eficientes.

A questão principal que emerge destas reflexóes é de que forma esta nova lógica de compreensão pode sobreviver dentro de um sistema que produz um movimento contrário (heterogestionário, competitivo, individualista) a este? Até que ponto estas aberturas ou frestas que vão sendo duramente cavadas dentro deste sistema são capazes ou suficientes para fazer implodir uma dinâmica, que como diria Foucault, encontra-se tão incrustada em nosso modo de estar e ser?

Será nesta direção que autores como Grade e Aued (2003) apontam Aníbal Quijano, Boaventura de Souza Santos, César Rodríguez e Carlos Vainer como críticos que, embora ressaltem a positividade dos experimentos de economia solidária, tecem importantes observaçóes quanto ao seu limite. 
Com efeito, para Quijano (2002), nenhuma das propostas alternativas ao modo de produçáo capitalista apresentam questionamentos radicais ao padrão de poder do capitalismo, pois falta-lhes vitalidade e viabilidade para que se tornem uma organização tão poderosa, flexível e de comprovada capacidade de adaptação, como é o capital e o capitalismo. Somente assim poderiam apresentar-se como um modo alternativo de produção.

Santos e Rodríguez (2002), por sua vez, acentuam que nenhuma dessas novas propostas representa uma alternativa ao capitalismo, ou seja, não se apresentam como um novo modo de produção, porque, segundo eles, ainda não aprendemos a fazer uma economia funcionar tendo por base a generosidade, embora essas alternativas sejam importantes na condição de potencialidades emancipatórias.

Por fim, Grade e Aued (2003) comentam que, segundo Carlos Vainer, a economia solidária só será uma proposta alternativa não capitalista, na medida em que ela se constituir num espaço em que se vivem as várias formas de sociabilidade do mundo do trabalho, a solidariedade, o sentimento de pertencimento a um grupo.

Gaiger (2000) acredita que a economia solidária estaria apontando para a possibilidade de criação de uma forma social de produção diferente, que convive com a produçáo capitalista. Já para Lisboa (2001), esta foi concebida para atuar fora da esfera estatal e em paralelo à economia mercantil, fundando-se na tradição familiar, na economia camponesa, no trabalho por conta própria, nos empreendimentos autogestionários.

Machado e Ribas (2001) acreditam ser o objetivo central da economia solidária a geração de possibilidades econômicas destinadas à reintegração dos excluídos pela ordem neoliberal de forma que passem a pertencer novamente ao processo de produção e, portanto, com possibilidade de trabalho e de renda. Para compreender a lógica da economia solidária, segundo Singer (2000), é fundamental considerar a crítica operária e socialista ao capitalismo, que condena a ditadura do capital nas empresas e o poder ilimitado que o direito de propriedade dá ao dono dos meios de produção.

Náo obstante, a economia solidária está em franco processo de constituição e de estruturação através do associativismo, ${ }^{6}$ como um movimento social forte e articulado, calcada sob princípios de liberdade de adesão, gestão democrática e participativa, e igualdade de participação econômica.

\footnotetext{
${ }^{6}$ Associaçôes são quaisquer grupos sociais unidos em torno de uma finalidade específica e com estatuto orientado pelo Código Civil Brasileiro de 2002.
} 


\subsection{O campo da economia solidária no Brasil}

Atualmente, no Brasil, mais de 50\% dos trabalhadores/as, sobrevivem à margem do modelo de relaçóes assalariadas e protegidas pelo sistema capitalista hegemônico. Sob diversas formas de nomeação, ${ }^{7}$ inúmeras práticas de relaçóes econômicas e sociais têm emergido visando, de imediato, a sobrevivência e a melhoria da qualidade de vida de milhóes de pessoas. Dados recentes da Secretaria Nacional de Economia Solidária (Senaes) ${ }^{8}$ revelam que existem, aproximadamente, 14,954 empreendimentos econômicos solidários, no Brasil, distribuídos em 2,274 municípios da federação.

Neste cenário, é importante distinguir experiências de fachada daquelas que efetivamente se reconhecem e assumem-se como empreendimentos econômicos solidários. Isto porque o horizonte da economia solidária no Brasil está além da mera sobrevivência, na medida em que propóe o desenvolvimento de práticas fundadas em relações de colaboração solidária, inspiradas por valores culturais que colocam o ser humano como sujeito e finalidade da atividade econômica, em vez da acumulação privada de riqueza em geral e de capital em particular.

Com efeito, ainda que o trabalho seja um dos valores centrais da economia solidária, ao buscar-se a unidade entre produção e reprodução, busca-se evitar a contradição fundamental do sistema capitalista, que desenvolve a produtividade, mas exclui crescentes setores de trabalhadores do acesso aos seus benefícios. Além disso, na proposta da economia solidária, a eficiência não pode limitar-se aos benefícios materiais de um empreendimento, mas se define também como eficiência social, em função da qualidade de vida e da felicidade de seus membros.

Desse modo, na medida em que apresenta alternativas viáveis para a geração de trabalho e renda e para a satisfação direta das necessidades de todos, buscando provar que é possível organizar a produção e a reprodução da sociedade de modo a eliminar as desigualdades materiais e difundir os valores da solidariedade humana, o campo da economia solidária pretende ser um poderoso instrumento de combate e reflexão sobre os mecanismos que geram a exclusão social.

Confrontando-se contra a crença de que o mercado é capaz de autoregular-se para o bem de todos e que a competição é o melhor modo de relação entre as pessoas, a economia solidária se oferece como uma proposta de desenvolvimento integral que visa a sustentabilidade, a justiça econômica, social, cultural e ambiental e a democracia participativa.

\footnotetext{
${ }^{7}$ Economia social, socioeconomia solidária, humanoeconomia, economia popular e solidária, economia de proximidade, economia de comunhão, etc.

${ }^{8}$ Sistema Nacional de Informações em Economia Solidária (sIEs), http://www.mte.gov.br/ ecosolidaria/sies.asp, 12-vI-2007.
} 
Através do exercício da economia solidária podemos ver acolhidas inúmeras experiências de diferentes contextos socioculturais, que ganharam múltiplas formas e maneiras de expressar-se e que se alimentam de fontes muito diversas como, por exemplo, as práticas de reciprocidade dos povos indígenas de diversas regiōes do país, do movimento dos quilombolas, das organizaçóes diversas que emergem do meio popular, como associaçóes, clube de trocas entre outras experiências.

É a partir deste contexto híbrido, que queremos avançar no debate sobre a Economia Solidária. Visualizamos nesta experiência -que não intenciona apenas incluir os ditos excluidos-a possibilidade para pensar um outro espaço de criaçáo e recriação constante da vida e do próprio sentido da solidariedade. Recriação esta que só é possível se formos capazes de resgatar e compreender os diferentes significados culturais das vivências humanas e de que forma vamos encontrando sentido para o estar junto com Outro, para o trabalho, para a vida. É dessa forma que Boaventura Souza Santos (2000) comenta que, só será possível pensar uma nova epistemologia quando tivermos condiçóes de repensarmos as diferentes dimensóes marginalizadas pela lógica violenta da regulaçáo, que são: a solidariedade (dimensão ética), a participação (dimensão política) e o prazer (dimensão estética).

\section{A interculturalidade como uma nova epistemologia}

O que significa pensarmos a economia solidária desde a perspectiva da interculturalidade? Quais as implicaçóes de um pensar intercultural na reflexão de uma prática que parece estar sendo sistematizada, como mencionávamos acima, através de conceitos, instrumentos e mesmo metodologias que estão profundamente imersas numa racionalidade ocidental? O que significaria, por exemplo, pensarmos a economia (oikós, nomia) a partir das culturas indígenas em que o próprio conceito de oikós (casa), trabalho, e de vida assumem diferentes sentidos? A própria palavra economia já encontra-se encerrada num universo cultural determinado e seu movimento que parte do local ao global passa a ser garantidor de uma hegemonia, que naturalmente penetra na nossa forma de ler e pensar a ordem (nomia) do mundo. Mas mesmo assim, por mais provocador que possam ser essas relaçôes, pensar a Economia Solidária desde a interculturalidade é mais do que pensar os sentidos que determinados conceitos assumem em culturas diversas.

A interculturalidade nos propõe, em um primeiro momento, mergulharmos em vivências culturais distintas para que possamos através desse mergulho sermos capazes de oferecer, de trocar, de nos misturarmos à elas, construindo assim um outro espaço, em que o intercultural possa signi- 
ficar uma assustadora e apaixonante abertura ao Outro. É importante percebemos que as culturas não significam lugares fixos, que calcificam identidades, assim a interculturalidade promove uma reflexão sobre a própria noção de cultura, possível a partir da extraterritorialidade, do além das fronteiras demarcadas pela cultura vista enquanto tradição.

Raul Fornet-Betancourt, quando comenta o significado da interculturalidade nos diz que,

...a interculturalidade quer designar, antes, aquela postura ou disposição pelo qual
o ser humano se capacita para, e se habitua a viver "suas" referências identitárias
em relação com os chamados "outros", quer dizer, compartindo-as em convivência
com eles. Daí que se trata de uma atitude que abre o ser humano e o impulsiona
a um processo de reaprendizagem e recolocaçáo cultural e contextual. É uma ati-
tude que, por nos tirar de nossas seguranças teóricas e práticas, permite-nos per-
ceber o analfabetismo cultural do qual nos fazemos culpáveis quando cremos que
basta uma cultura, a "própria" para ler e interpretar o mundo (2004: 13).

O que significaria abrir o ser humano? Admitiríamos então um humano encarcerado em si mesmo que se vê, diante do Outro, provocado a sair de si e ir em direção ao Outro; o Outro seria aquele que arromba este espaço seguro, dito humano, mas diante deste arrombamento o que restaria de humano? Estaríamos aqui diante de uma outra compreensão do humano, nem pronto, nem fechado, mas um humano que se dá no movimento mesmo de ir até o Outro, um humano que se constrói no diálogo; um humano que não surge como condição do diálogo, mas o diálogo é que surge como condição do humano. A interculturalidade seria então a possibilidade mesma desse diálogo.

$\grave{E}$ interessante percebemos que a palavra interculturalidade não aparece nos dicionários brasileiros, esse sentido deve ser construído, não está dado. ${ }^{9}$

A palavra intercultural é composta por duas palavras inter e cultura. Inter vem do latim que corresponde a entre, podendo assumir o sentido de uma interposiçáo no tempo, no espaço, uma reciprocidade, um quase ou início de uma ação. $\mathrm{O}$ intercultural sugere em si mesmo um estado de entre, de interstício, ou seja, não estar nem lá nem aqui, mas entre dois universos culturais que passariam a necessitar de um deslocamento para se chegar ao entre. Mas o entre é também reciprocidade, diálogo cultural, encontro com o Outro. Assim o entre propóe o encontro, convite a esse deslocamento que é permeado pelo estranhamento do próprio movimentar-se. Desse modo, o diálogo intercultural, assume um sentido no seu acontecer mesmo, não nasce como conceito mas como ação, movimento para o Outro.

${ }^{9}$ Cf. Menezes (2003: 113-114). 
A Interculturalidade contempla a necessidade de desenvolvermos uma visão complexa das sociedades de hoje, considerando que as mesmas são atravessadas por múltiplas narrações culturais e identitárias, afastando-se assim de uma perspectiva homogeneizadora da cultura e dos sujeitos, renunciando a um modo de organização social, econômico, político, estético, ético baseado e estruturado em torno de um único modelo de cultura e de sujeito.

\subsection{As dimensóes do político, da ética e da estética do diálogo intercultural}

Nossa pesquisa ${ }^{10}$ tem nos proporcionado compreender dimensōes da vida onde sujeitos que supostamente tiveram amputadas a sua capacidade de desejar, se percebem desejantes dentro de uma sociedade capitalista, em que o desejo se confunde com a mera necessidade de consumir. Desejamos coisas: ter uma casa, um carro, pessoas. Porém, conforme Deleuze (apud. Agamben, 2007) o desejo assume outra dimensão, não visa a satisfação, a completude, mas se nutre sempre de mais desejo, simplesmente deseja-se.

Ao acompanharmos várias reunióes tanto do Fórum Municipal de Economia Solidária de Novo Hamburgo(Rs) como do Fórum Regional do Vale do Sinos/Rs, várias falas, gestos, silêncios vão traduzindo para nós o significado desse desejo. Destacamos aqui a fala de um representante de um empreendimento durante uma reunião do Fórum Regional: "me sinto sem tesão, como se não tivesse mais força, mesmo dentro da economia solidária parece que estou por fora, não entendo o que é dito" (Informante A, diário de campo, 2009).

No mesmo instante, diante de uma fala que expressa as contradiçóes deste espaço, escutamos interpelação de outra pessoa:

...a gente como empreendimento temos que nos apropriar mais para saber se posicionar. Temos força, sabemos as necessidades e quanto precisamos de força para trabalhar; força temos sim e não é porque somos humildes, simples que não sabemos falar, que eles são melhores, eles não são donos do espaço. Já vi muita coisa bonita acontecendo na organizaçáo do povo (Informante B, diário de campo, 2009).

As expressôes "não entendo o que é dito", "não sabemos falar" trazem a tona não apenas as contradiçóes de uma outra lógica de relaçóes que

\footnotetext{
${ }^{10}$ Nos referimos a pesquisa que desenvolvemos na Feevale intitulada "Educação, trabalho e solidariedade", CNPq, em que buscamos acompanhar as discussóes do Fórum Municipal de Economia Solidária de Novo Hamburgo e do Fórum do Vale do Sinos, para desse modo, compreender de que forma esta experiências políticas contribuem na organização dos empreendimentos de economia solidária.
} 
busca se impor na contramão de um sistema ancorado na exploração do Outro; mas o quanto esta nova lógica necessita repensar sua própria linguagem, para que o dito seja a expressão da diferença e não a tradução de uma identidade. É nessa perspectiva que pensar a interculturalidade como um elemento fundamental na construção da economia solidária nos proporciona uma outra forma de fazer e compreender o político.

A organização da economia solidária no Brasil se depara com muitas dificuldades de diferentes ordens. Podemos constatar e afirmar estas dificuldades a partir das nossas aproximaçóes aos espaços coletivos dos empreendimentos, entidades de apoio e poder público que, conjuntamente, dão forma aos fóruns.

Nestes espaços temos sistematizado e pensado práticas de economia solidária para além da geração de trabalho e renda entendendo que estas traduzem a possibilidade de demonstrar a economia solidária como uma experiência intercultural.

Para aprofundarmos a análise sobre estas dificuldades resgatamos as três dimensóes (política, ética e estética) anunciadas por Boaventura Souza Santos o qual afirma que para fazer emergir um novo paradigma, chamado pelo autor de conhecimento prudente para uma vida decente precisamos:

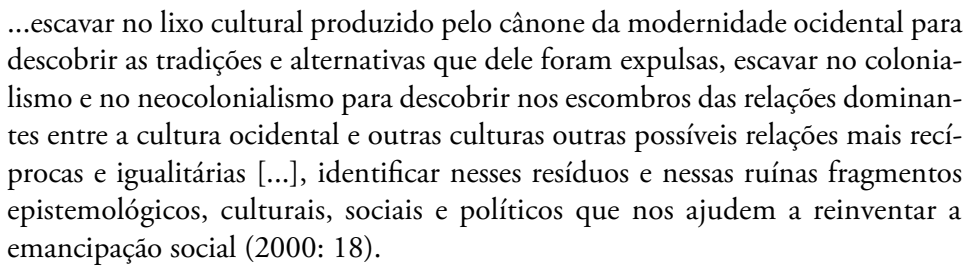

Boaventura comenta nessa obra que a modernidade ocidental viu-se ancorada por dois grandes pilares: a regulação (estado, mercado e comunidade) e a emancipaçáo (racionalidade cognitivo-instrumental, moral e prática da ética e estético-expressiva). A questâo principal se dá no fato desse projeto ter se preocupado muito mais em desenvolver alguns aspectos desses princípios em detrimento de outros. Escavar o lixo cultural da modernidade seria então resgatar esses aspectos marginalizados, representados aqui pela reconstrução de um conhecimento-emancipação onde a comunidade e a racionalidade estético-expressiva passariam a ser elementos fundamentais. E é a partir desses dois campos que compreenderemos a economia solidária como uma epistemologia intercultural, ou seja, produtora de um saber que nasce das diferentes realidades dos sujeitos envolvidos, mas que ao mesmo tempo, é capaz de se abrir para o diálogo e releitura desses saberes. 
Dos registros de encontros mensais que têm acontecido desde o ano de 2006 e das incursóes das pesquisadoras em atividades anteriores no campo social temos verificado o quanto as experiências que se constituem no entorno da economia solidária formulam um novo discurso (capturados em fragmentos das atas das reunióes) com temáticas que evidenciam a contextualização das vivências e das práticas que brotam destes encontros que, ao mesmo tempo em que reafirmam o que se reproduz nos empreendimentos (dentro da lógica da individualidade) faz emergir a experiência do comunitário.

Segundo Santos (2000), a comunidade foi perdendo sua importância na medida em que a sociedade foi assumindo seu sentido. A transformaçáo paulatina da comunidade para a sociedade representa a forma mesma do campo político ser pensado. A comunidade seria ainda o lugar do diálogo, dos encontros, da participação e da solidariedade. Podemos perceber o surgimento das sociedades através da ampliação e organizaçôes das cidades, espaços geográficos que reconfiguram as organizaçóes sociais, em que o que antes era comum (comunitário) não se torna tão evidente. $\mathrm{A}$ participação se dá então no nível do representativo, cria-se a figura do político profissional, pago para mediar nossos desejos e falas. Os diferentes movimentos sociais, legitimados por esta lógica, acabam fragilizados pela exacerbação dessa idéia mesma de representaçáo, pois os sujeitos (representados) vão se distanciando de seus espelhos representativos a ponto de não mais conseguirem se ver através deles. $\mathrm{O}$ espaço político perde o sentido do comum, o sentido do comunitário.

Temos observado estes aspectos que se expressam como limites nos empreendimentos, principalmente naqueles segmentos em que a produção se faz solitária, as quais se organizam mais pela necessidade da comercialização, a exemplo do artesanato. Noutros segmentos, entre eles a reciclagem (onde há maior organização) espaços como as assembléias denotam a figura do intérprete (alguém que emerge sendo o especialista) aquele que tem o direito de falar por todos. Ao mesmo tempo, os Fóruns tem-se apresentado como um importante exercício e vivência do sentido mesmo do comunitário. Tanto as experiências solitárias como as mais tradicionais em termos de organização se vêem confrontadas no espaço público dos fóruns (principalmente o municipal, onde não existe a figura do coordenador ou representante, tornando-se um espaço aberto, inclusive aos empreendimentos que não se identificam com a economia solidária mais diretamente). Ali se discute as dificuldades dos grupos, buscam-se alternativas, e os grupos percebem que suas dificuldades também são vividas por outros grupos. Assim, o espaço do Fórum acaba representando a possibilidade efetiva de organização desses grupos, do sentido do comunitário. 
Resgatar o comunitário passaria necessariamente pela necessidade de reinventarmos o político, traduzindo a participaçáo e a solidariedade a partir de uma outra ordem. Nesse sentido a economia solidária pode fazer de ambos os aspectos elementos fundamentais para sua construção. A idéia de autogestão, por exemplo, exige dos trabalhadores/as refletirem de que forma produziráo coletivamente um espaço comum, em que a multiplicidade é a condição mesma do comum. Também a solidariedade é o conhecimento obtido nesse processo "sempre inacabado, de nos tornarmos capazes de reciprocidade através da construção e do reconhecimento da intersubjetividade" (Santos, 2000: 81). Este coletivo é capaz, portanto, de promover subjetividades politicas, saímos de nossa condição de massa, para pensarmos a multidâo, no sentido definido por Negri e Hardt, onde a multidão "pode ser encarada como uma rede: uma rede aberta e em expansão, na qual todas as diferenças podem ser expressas livre e igualitariamente, uma rede que proporciona os meios da convergência para que possamos trabalhar e viver em comum" (2005: 12). Rede esta que também é possível de ser observada nos empreendimentos de economia solidária já consolidados ou em vias de consolidação.

Além disto, temos percebido um movimento interessante, de aproximação e de distanciamento, de grupos populares e de empresas do setor de serviços que vivem nos Fóruns um espaço em que o diálogo entre pares parece ser possível. Contudo, observamos também que quando alguns grupos não se reconhecem naqueles espaços deixam de participar das reuniōes.

Para refletirmos sobre a estética desse comunitário a racionalidade estético-expressiva assume uma importância fundamental. $\mathrm{O}$ estético aqui não representa apenas uma plástica de estar e conviver que traduziria de alguma maneira o belo dessas relaçóes. $\mathrm{O}$ estético-expressivo é permeado pelo caos, pela indefiniçáo das formas, pela diversidade de sentimentos, pela forma como tocamos o mundo e como nos sentimos por ele tocados. O prazer é, nesse sentido, a experiência estética extrema dessa racionalidade, ou seja, toda compreensão nasce deste prazer. Enquanto que a racionalidade instrumental afastou esta dimensão, entendemos que a economia solidária pode produzir uma racionalidade estética em que o prazer torna-se essencial. Por isso, recuperando a fala descrita anteriormente por um integrante de um dos fóruns da economia solidária -marcada a perda de tesão- compreendemos quanto a dimensão do prazer é importante para que possamos pensar uma outra forma mais participativa e solidária de relaçôes humanas. 


\section{Consideraçóes finais}

Pensar a economia solidária desde uma perspectiva intercultural é proporse a repensar o próprio estatuto do que aqui estamos chamando econômico e solidário. Pensar a partir da interculturalidade supóe a capacidade de incorporar na própria prática novas linguagens e narraçóes. A economia solidária torna-se então um espaço de promoção do diálogo intercultural, onde nem as culturas nem as identidades devem ser compreendidas como imutáveis, podendo ser revisadas e/ou modificadas. Assim, nenhuma referência cultural é absoluta, toda idéia ou posição é debatida no coletivo, assumindo uma importância fundamental não devendo ser desconsiderada. O diálogo, deste modo, incorpora o conflito. A economia solidária representaria o espaço e lugar da comunicação e negociação, do encontro e desencontro e, finalmente, da convivência. Negar o conflito é impossibilitar o diálogo e toda possibilidade de comunicação. A interculturalidade é então uma pedagogia dos encontros, mas não dos encontros entre culturas e identidades perfiladas e sim entre a indefinição e o ambíguo das culturas e identificaçōes dos sujeitos. É nesse sentido que habituais disputas entre as entidades de apoio, ao contrário de serem fomentadas pela tradicional lógica que defende a necessidade de aprenderse a disputar, podem ser contestadas pela afirmação de que os fóruns são espaços de contradição.

É sob estas condiçóes que a economia solidária deve ser pensada, pois através do diálogo intercultural, a diversidade de saberes passa a representar um elemento fundamental para a construção de outras lógicas de convivência e de relaçóes com o mundo. É a partir desses elementos que podemos pensar a economia solidária como um campo de atuaçáo que desestrutura o que Foucault irá chamar de Biopoder. "Biopoder é a forma de poder que regula a vida social por dentro, acompanhando-a, interpretando-a, absorvendo-a e a rearticulando" (Negri e Hardt, 2005: 43). Foucault comenta que é possível acompanhar a trajetória de uma sociedade que se organizava a partir da disciplina para uma sociedade de controle. Na sociedade de controle o que passa a animar esta engrenagem é o controle da vida, que de alguma forma vai produzindo novas subjetividades. Quando a economia solidária não pretende repensar apenas o lugar do trabalho, mas toda relação que o sujeito tem com a vida, percebemos a profundidade e abrangência desta proposta. Ao mesmo tempo, como o poder é tentacular (náo mais localizado), abrange a totalidade das relações sociais, ele também é plural e múltiplo. $\mathrm{O}$ que percebemos ou definimos como local (com certo purismo cultural) não pode ser visto como um universo separado, que não nos diz respeito, ou que para se preservar deva ser ostracizado, pois o Outro sempre é uma ameaça. É 
claro que estas questóes são muito delicadas, no momento que estamos também falando de culturas que foram (ou estáo sendo) totalmente exterminadas em nome de uma incontornável e irreversível globalização. No entanto, quando falamos de uma sociedade em que nossas açóes (queiramos ou não) produzem efeitos àqueles que parecem estar táo distantes, estamos falando de um tempo em que a própria noção de tempo (e espaço) é ressignificada.

Por isso, no debate sobre a economia solidária é fundamental nos perguntarmos como estamos produzindo essas ressignificaçóes, como reinventamos formas de resistências e de organizaçóes sociais capazes de pensar a vida além do próprio humano. E o que é a vida? Para seguir Deleuze (apud Agamben, 2007 p.85) dizemos que a vida é o campo de imanência variável do desejo. A vida não é apenas um projeto individual, singular, resistindo à morte, mas a vida é criadora de desejos; um desejo que não é único, é variável e múltiplo. Não há uma forma mais legítima, mais potente de desejar, deseja-se e é nesse movimento que nos fazemos e vamos tecendo a vida.

\section{Referências}

Agamben, Giorgio (2007), "La inmanencia absoluta", in Gabriel Giorgi y F. Rodrigues (comps.), Ensayo sobre biopolitica: excesos de vida, Paidós, Buenos Aires.

Fornet-Betancourt, Raul (2004), Interculturalidade: críticas, diálogos e perspectivas, Nova Harmonia, São Leopoldo.

Gaiger, Luiz Inácio (2000), "Os caminhos da economia solidária no Rio Grande do Sul”, in Paul Singer y André Ricardo de Souza (orgs.), A economia solidária no Brasil, Contexto, São Paulo.

Gaiger, Luiz Inácio (2001), “As organizaçóes do terceiro setor e a economia popular solidária", Revista de Ciências Sociais, 159, Unisinos, Sáo Leopoldo, pp. 103-151.

Grade, Marlene e Idaleto Malvezzi Aued (2003), "Apontamentos de estudo sobre novas relaçóes sociais na economia solidária", in II Seminário Internacional de Educação Intercultural, Gênero e Movimentos Sociais: identidade, diferença e mediaçóes, UFSC, http://www.rizoma.ufsc.br, 4-vII-2006. 
Lisboa, Armando de Melo (2001), "A sócioeconomia solidária diante da grande transformaçáo", Revista de Ciências Sociais, 159, Unisinos, São Leopoldo, pp. 27-57.

Machado, Luiz Carlos Pinheiro e Clarilton Edzard Ribas (2001), Economia solidária: solução ou engodo?, UfSC, Florianópolis [digitado].

Mance, Euclides André (2000), A revolução das Redes: a colaboração solidária como uma alternativa pós-capitalista à globalização atual, Vozes, Petrópolis.

Menezes, Magali Mendes de (2004), "Um texto no feminino atravessado pela diferença: uma leitura de Nietzsche através de Derrida", in Neusa Vaz Silva e M. Back (org.), Temas de Filosofia Intercultural, Nova Harmonia, São Leopoldo.

Negri, Antonio e Michael Hardt (2005), Multidão: guerra e democracia na era do império, Record, São Paulo.

Quijano, Aníbal (2002), “Sistemas alternativos de produção?”, in Boaventura de Souza Santos (org.), Produzir para viver - os caminhos da produção não capitalista, Civilização Brasileira, Rio de Janeiro.

Razeto, Luís. "La economia de solidaridad: conceito, realidad y proyecto", Persona y Sociedad, 13 (2), Santiago do Chile, pp. 1-19, <http:// www.desarrollohumanosostenible.org/pdf/5_la_economia_de_ solidaridad.pdf $>$, 15-11-2007.

Santos, Boaventura de Souza e César Rodríguez (2002), "Para ampliar o cânone da produçáa”, in Boaventura de Souza Santos (org.), Produzir para viver - os caminhos da produção não capitalista, Civilização Brasileira, Rio de Janeiro.

Santos, Boaventura de Souza (2000), A crítica da razão indolente: contra o desperdício da experiência, Cortez, São Paulo.

Singer, Paul (2000), "Economia solidária: um modo de produção e distribuição", in Paul Singer e André R. de Souza (orgs.), A economia solidária no Brasil: a autogestão como resposta ao desemprego, Contexto, São Paulo, pp. 11-30. 
Singer, Paul (2002a), Introdução à economia solidária, Editora Fundação Perseu Abramo, São Paulo.

Singer, Paul (2002b), "A recente ressurreição da economia solidária no Brasil", in Boaventura de Souza Santos (org.). Produzir para viver - os caminhos da produção não capitalista, Civilização Brasileira, Rio de Janeiro.

Singer, Paul (2003), "Economia solidária”, in A. D. Catani (org.), A outra economia, Veraz Editores, Porto Alegre.

Recibido: 10 de enero de 2008. Reenviado: 15 de junio de 2010. Aceptado: 21 de junio de 2010.

Dinora Tereza-Zuchetti. Professora Pesquisadora da Feevale. Doutora em Educação pela Universidade Federal do Rio Grande do Sul (Ufrgs). Membro do Grupo de Pesquisa Educação, Cultura e Trabalho - Feevale e do Grupo de Estudos Gestão do Cuidado em Educação - UfrGs.

Eliana Perez-Gonçalves de Moura. Professora Pesquisadora da Feevale. Doutora em Educação pela Pontifícia Universidade Católica do Rio Grande do Sul (pucrs). Coordenadora do Grupo de Pesquisa Educação, Cultura e Trabalho - Feevale.

Magali Mendes-de Menezes. Professora-Pesquisadora da Feevale/NH, integra o Grupo de Pesquisa Educação, Cultura e Trabalho, Doutora em Filosofia, Vice-presidente da Associação Sul Americana de Filosofia e Teologia Interculturais (ASAFTI). 